\title{
Creation of Tantric Sacred Spaces in Eastern Central Asia
}

\author{
Carmen Meinert
}

\section{Introduction}

The spread of Tantric Buddhism in Eastern Central Asia between the 1oth and early $13^{\text {th }}$ centuries is well documented in textual and visual evidence from various sites. Among the earliest dateable textual evidences of Tantric Buddhism in Eastern Central Asia are the Tibetan Dunhuang manuscripts from the second half of the 1oth century, as recent palaeographic research by Sam van Schaik and Jacob Dalton shows. ${ }^{1}$ So far, these manuscripts have been used mostly by scholars of Tibetan Studies, for whom they are seen as constituing auxiliary materials to the reconstruction of early Tibetan Buddhist historyparticularly valuable due to the lack of equivalent materials for this period deriving from Tibet itself. However, to my knowledge none have so far looked at Eastern Central Asian Buddhism as an integrated system in itself, which also influenced the development of Buddhism in Tibet (and in the Sinitic world as well). As an example, in my earlier work, I examine individual interesting manuscripts from the Dunhuang Collection, without addressing the larger context in which these were actually produced. I failed to question what these manuscripts actually meant for the local Eastern Central Asian communities themselves. ${ }^{2}$ However, here I suggest that with a deeper knowledge of the spread of

1 Jacob P. Dalton, Tom Davis, and Sam van Schaik, "Beyond Anonymity: Paleographic Analyses of the Dunhuang Manuscripts," Journal of the International Association of Tibetan Studies 3 (2007): 18, accessed November 29, 2017. <http://www.thlib.org?tid=T3106 >. The catalogue of the Tibetan Tantric manuscripts from the Dunhuang Collection stored in the British Library is published in Jacob P. Dalton and Sam van Schaik, Tibetan Tantric Manuscripts from Dunhuang: A Descriptive Catalogue of the Stein Collection at the British Library (Leiden, Boston: Brill, 2006). Cf. also Xinjiang Rong, "The Nature of the Dunhuang Library Cave and the Reasons for Its Sealing," Cahiers d'Extrême-Asie 11 (2000-1999): 247-275; Rong Xinjiang 荣新江, “Zailun Dunhuang zangjing dong de baozang一Sanjie si yu zangjing dong 再论敦煌藏经洞 的宝藏一三界寺与藏经洞 [Further Discussion on the Treasure in the Library Cave of Dunhuang-Three Stages Monastery and the Library Cave]," in Dunhuang xue xinlun 敦煌 学新论 [New Contributions to Dunhuang Studies], ed. Rong Xinjiang 荣新江 (Lanzhou: Gansu jiaoyu chuban she, 2002), 8-28, especially pp. 18-19.

2 See for example my articles: Carmen Meinert, "The Conjunction of Chinese Chan and Tibetan rDzogs chen Thought: Reflections on the Tibetan Dunhuang Manuscripts IOL Tib J 689-1 and 
Tantric Buddhism in Eastern Central Asia, new insights will emerge for its spread in Tibet, and by extension in the Sinitic world.

After the demise of the Tibetan Empire in 842, and its dominon over large parts of Eastern Central Asia, the model of state-sponsored Buddhism in effect during Tibetan rule was replaced with a model of dispersion, in which Buddhist practice and ideology were widely adopted by local actors in Eastern Central Asia. Interestingly, Tibetan continued to be used as a lingua franca, until at least the middle of the 11th century, and probably even later. ${ }^{3}$ With it Tantric Buddhism as evidenced in the Dunhuang manuscripts developed into a flexible system for group formation that cut across boundaries of class, clan, and ethnicity, extending to various locations in the Central Asian Buddhist network (as Sam van Schaik recently shows). ${ }^{4}$ However, as new political rules with new and strong imperial patronage systems were established in Eastern Central Asia (particularly by the Tanguts and Uyghurs) (map o.1 of this volume), the latest ritual techniques, such as the Cakrasaṃvara and Vajravārāhī rites, were also translated into local vernaculars, such as Tangut, Chinese, and Uyghur, as evidenced in local artistic production. This step in the transmission of Tantric Buddhism in Central Asia is visible in visual (and textual) materials-expecially as it developed under Tangut rule (ca. 1038-1227, in Chinese sources known as Xixia 西夏), examples of which I address in this article. That material provides evidence of the continuation of Tantric transmissions beyond the 1oth century textual production at Dunhuang (敦煌) — a fact that has only recently been acknowledged by scholars and as yet hardly researched systematically. I argue that in the late 12th century, most likely under the rule of the Tangut Emperor Renzong (r. 1139-1193, 仁宗), a transition is visible in visual depictions from (predominantly Sinitic styles of) Mahāyāna and Esoteric Bud-

PT 699," in Contributions to the Cultural History of Early Tibet, ed. Matthew T. Kapstein and Brandon Dotson (Leiden, Boston: Brill, 2007), 239-301; Carmen Meinert, "Between the Profane and the Sacred? On the Context of the Rite of 'Liberation' (sgrol ba)," in Buddhism and Violence, ed. Michael Zimmermann (Lumbini: Lumbini International Research Institute, 2006), 99-130.

3 Given the evidence of Tibetan manuscripts from the Karakhoto Collection which postdate the Dunhuang Collection, it is not unlikely that Tibetan continued to be used among Tantric Buddhist communities in Eastern Central Asia beyond the 11th century. Tsuguhito Takeuchi and Maho Iuchi provisionally date Tibetan texts from the Karakhoto Collection to three time periods: the 11th to 12th c., the 12th to 13th c. and the 13th to 15th c. See Tsuguhito Takeuchi and Maho Iuchi, eds., Tibetan Texts from Khara-Khoto in the Stein Collection of the British Library: Studies in Old Tibetan Texts from Central Asia (Tokyo: Toyo Bunko, 2016), 10.

4 Sam van Schaik, "Tibetan Buddhism in Central Asia: Geopolitics and Group Dynamics," in Transfer of Buddhism across Central Asian Networks (7th to 13th Centuries), ed. Carmen Meinert (Leiden: Brill, 2016), 57-81. 
dhism to Tibetan Tantric Buddhist transmissions. It was under Tangut imperial patronage that Tantric Buddhist imagery was produced in Eastern Central Asia for the first time on a large scale-both in the form of murals in caves, as well as in the form of thangkas stored in Buddhist architectures and instutions. My intent is to analyse these examples of visual production not from an art historical perspective, but rather from the perspective of an interdisciplinary Bildwissenschaft as developed by Hans Belting. Belting argues that one should trace images (Germ. Bilder) as cultural practices (Germ. Kulturpraktiken), and analyse religious images as a fundamental commodity of a given religious practice. In his magnum opus, Likeness and Presence. A History of the Image before the Era of Art (first published in 1990 in German with the title Bild und Kult: eine Geschichte des Bildes vor dem Zeitalter der Kunst) he writes:

We can therefore consider these cult images, or "holy images," as Edwyn Bevan has called them in his book of that title, only if we adopt a historical mode of argumentation that traces them back to the context in which they historically played their part. These images represented a local cult or the authority of a local institution, not the general beliefs of a universal church. ${ }^{5}$

Therefore, the cultic potency attributed to such images is only understandable through situating them within social practices and their respective local historical contexts.

Much in line with this, I relate the presence of visual materials at different locations within the Tangut Empire to each other, considering them from a network approach. This is a promising approach for determining how visual images in the Tantric Buddhism of the Tangut Empire (1) support state-protection and legitimation, (2) present the emperor as an Aśokan-style Buddhist ruler, and (3) attest to the growing popularity of Tantric Buddhist practices for purely private soteriological purposes (also from the perspective of the ruler). ${ }^{6}$ Thus, a key component in the ongoing process of buddhicisation of Eastern Central Asian lands was the Tangut territory as a sacred environment filled with pagodas, stūpas, monasteries, and caves. These elements were mediums through which the Buddhist divine was seen, visualised, and experienced.

5 Hans Belting, Likeness and Presence. A History of the Image before the Era of Art, trans. by Edmund Jephcott (Chicago, London: The University of Chicago Press, 1996), 3. For the German version of the quote see: Hans Belting, Bild und Kult: Eine Geschichte des Bildes vor dem Zeitalter der Kunst, 7 th edition (Munich: Beck, 2011), 14.

6 Rob Linrothe, "Xia Renzong and the Patronage of Tangut Buddhist Art: The Stūpa and Ushnīshavijayā Cult," Journal of Sung-Yuan Studies 28 (1998): 93-94. 
They represent a thorough transformation that would not have been possible without extensive imperial patronage.

\section{2 Tangut Buddhist Patronage: The Background}

Before moving to the concrete examples, I provide a brief outline on the background to the establishment of the Tantric Buddhist sites under the Tangut imperial patronage of Renzong in the second half of the 12th century. During Renzong's fifty-five year reign, the Tangut territory reached its greatest extent, and contained a multi-ethnic population of Tanguts, Chinese, Tibetans, Uyghurs, Khitans, and other peoples (map 10.1). ${ }^{7}$ These different groups were unified under an administrative system largely modeled after the Chinese one, with an educational and cultural programme installed by Renzong's father in the early 12th century. In 1145, Renzong promoted further measures to implement a Confucian style education for the official recruitment system of the Tangut state. In 1161, he established the Hanlin Academy (Chin. hanlin xueshi yuan 翰林學士院), which was in charge of compiling the historical records of the dynasty. ${ }^{8}$ Therefore, Renzong can be described as a very active ruler, who, at the height of the Tangut Empire, successfully transformed it into one of the major cultural and Buddhist centres in Central and East Asia at the time. ${ }^{9}$

Renzong and his family members, particularly his second empress from the Chinese Luo (羅) clan, were all fervent supporters of Buddhism. In fact, they continued the heritage of their predessors, for whom Buddhism played a major role. In the 11th century, these rulers mainly oriented themselves towards the Chinese Song Dynasty (960-1279, 宋). Between 1031-1073 six copies of the Chinese Buddhist canon were ordered from the Office for the Translation of Buddhist Scriptures (Chin. yijing yuan 譯經院). The Tanguts even copied that as a model, and set up a similar institution in their capital for the translation of the Buddhist canon from Chinese into Tangut. ${ }^{10}$

7 The production of this map was facilitated through the BuddhistRoad project which received funding from the European Research Council (ERC) under the European Union's Horizon 2020 research and innovation programme (grant agreement No. 725519). This map can also be downloaded under a creative common licence at $<$ https://buddhistroad.ceres.rub.de/en/ visual-aids/>.

8 For the interplay of Confucianism and Buddhism in the Tangut Empire, see also Chapter 5 "The Formation of Tangut Ideology: Buddhism and Confuciansm" in this volume by Kirill Solonin.

9 Ruth W. Dunnell, The Great State of White and High. Buddhism and State Formation in EleventhCentury Xia (Honolulu: University of Hawai'i Press, 1996), 23-26.

Dunnell, The Great State of White and High, 36-49. 
During the 12th century, Emperor Renzong continued and accelerated this process of the production of Buddhist knowledge. Among his most important acts of patronage that evidence the increasing institutionalisation of the Buddhist clergy and their activities, four stand out. (1) He regulated monastic affairs, as documented in the Tiansheng Law Code (Tianshen reign under Renzong (1149-1169/1170, 天盛)). (2) He introduced the extraordinary position of the Imperial Preceptor (Chin. dish $i$ 帝师), which according to Ruth Dunnell took place some time in the 1170s - at a time when the might of Renzong was briefly curtailed by a high-ranking officer and military man. After that, Renzong's authority was strengthened. Dunnell writes:

Establishment of the office of imperial preceptor may have been another, more personal, response aimed at enhancing the throne's spiritual authority and divine powers of protection. ${ }^{11}$

In fact, the establishment of the extraordinary position of the Imperial Preceptor coincided with the invitation of Tibetan Buddhist masters to the Tangut court (more about this further down). (3) He printed a new edition of the Buddhist canon (1149-1169). (4) He organised Buddhist ceremonies and the distribution of printed Buddhist sütras on a grand scale at special events, such as on the occasion of Renzong's 6oth birthday in 1184, and on the 5oth anniversary of his ascension to the throne in 1189. As Imre Galambos has pointed out:

If we were to take the Kozlov collection [i.e. the Karakhoto Collection in St. Petersburg] as a representative sample of the translation and publication activities in the Tangut state, twice as many dated Buddhist texts come from the time of [Renzong's] reign than from all other periods of the Tangut state together. ${ }^{12}$

Although the Tangut Empire is well-known for its dual orientation of Buddhist trends (Sinitic as well as Tibetan), a turning point in imperially favouring Tibetan Buddhism over (or at least alongside) Sinitic traditions coincides with the early days of Renzong's reign (after the third decade of the twelfth

11 Ruth Dunnell, "The Hsia Origins of the Yüan Institution of Imperial Preceptor," Asia Major, Third Series 5.1 (1992): 103.

12 Imre Galambos, Translating Chinese Tradition and Teaching Tangut Culture-Manuscripts and Printed Books Form Khara-Khoto (Berlin: de Gruyter, 2015), 112-113; the quote is found on p. 113. Linrothe also argues that the most productive period of carving and printing of Buddhist texts was under Renzong, cf. Rob Linrothe, "Peripheral Visions: On Recent Finds of Tangut Buddhist Art," Monumenta Serica 43 (1995): 243. 
century), when Tangut military problems with the Song Chinese court receded and Tibetan missionary activities to the Tangut court led to Tibetan Tantric Buddhism becoming truly international for the first time in its history. ${ }^{13}$ This example attests to how changing situations in the political field immediately impacted the religious field: In other words, demarcation processes in the political realm (the move away from the Chinese model of a 'civilised' state as the main inspiration) mirror religious demarcation processes extended to the Tibetan Buddhist representatives. Tibetan masters, mainly of the Kagyü School (Tib. bka' brgyud pa) were invited to the Tangut court, where some of them eventually enjoyed the privileged title of Imperial Preceptor. Probably for the first time in the history of Central Asian Buddhism, Tibetan Tantric Buddhism became institutionalised to a large degree.

To sum up: Apart from establishing a Chinese-style administration, Tangut imperial patronage of Buddhism played an important part in diplomatic relations with neighbouring cultures. Internally, the establishment of Buddhist sites in the form of actual physical spaces, through the building of temples, new monasteries, stüpas, caves, and repairing pre-existing monuments—such as the Yulin Caves (Chin. Yulin ku 榆林窟), the Mogao Caves (Chin. Mogao ku 莫高窟), the Gantong stūpa (Chin. Gangtong ta 感通塔) in Liangzhou (涼州) $)^{14}$ — were ongoing enterprises which intensified under Renzong's rule. The renovation of existing sites was most likely associated with the prestige of the throne. The renovation of existing sites and the creation of new sites were certainly not something new, but rather were the continuation of existing social and religious practices in the region-as was the case with Chinese and Tibetan rulers for centuries. After all, the Tanguts had inherited a thoroughly buddhicised land, or as Ruth Dunnell put it, the "[c] onquest of Hexi and acquisition of the classical Buddhist lands [...] brought new religious obligations and opportunities to the Tangut rulers." ${ }^{15}$ Yet one thing was new under the Tangut Emperor Renzong's rule, namely the shift in orientation from mainly (or solely) Mahāyāna Buddhist topics and depictions (doctrines as well as practices) to the inclusion of Tantric teachings and related visual material. Thus, it was under Tangut rule that the sacred geography of the region was enriched with the presence of Tantric Buddhist masters and deities.

13 Ruth W. Dunnell, "Esoteric Buddhism under Xixia (1038-1227)," in Esoteric Buddhism and the Tantras in East Asia, ed. Charles D. Orzech, Henrik H. Sørensen, and Richard K. Payne (Leiden, Boston: Brill, 2011), 467.

A summary in Chinese concerning the repare and repainting of caves in Yulin and Dunhuang during Tangut rule is given in: Dunhuang wenwu yanjiu suo 敦煌文物研究所, ed., Zhongguo shiku. Dunhuang Mogao ku 中國石窟。敦煌莫高窟 [Caves in China. The Mogao Caves in Dunhuang] (Beijing: Wenwu chubanshe, 1987), vol. 5, 175-185. 
I argue that in the process of establishing a network of Tantric sites, the Tanguts seem to have been inspired by the Tibetans, who developed such sites, thereby relocating what was originally an Indian sacred geography to their own land. Toni Huber convincingly argues that the Tibetans followed the pilgrimage routes of the Indian Tantric pith ha sites. Such sites were primarily understood as related to internal yoga practice meant to realise a mandala of a given deity within one's own body, i.e. as a vajra body (Skt. vajrakāya), also manifested in the external world with certain deities presiding in the geographical 'vajra body.' Religious feasts were performed at such sites, both internal yogic practices as well as externalised rituals. One of the sub-divisions of the sites in the pițha cultic circuit were the Eight Cemeteries (Skt. așta śmaśāna) or Charnel Grounds, in which Tantric ascetics performed meditation and rites. The Tanguts essentially continued this trend, and relocated the superimposed vajra body onto their own geographical realm. In this manner they connected themselves to a global Buddhist trend. Evidence of this network of sacred Tantric sites is found in the periphery of the Tangut territory, as well as at the centre, close to the Tangut capital of Zhongxing (中興, modern Yinchuan 銀川). ${ }^{16}$ I suggest that the production of Tantric art in the following sites should be understood as related, and as productions from a similar period in the late 12th century, namely in the periphery of the Tangut Empire: (1) in Dunhuang at the Mogao Caves, (2) in Yulin, (3) in the Eastern Thousand Buddha Caves (Chin. Dong Qianfodong 東千佛洞) near Guazhou (瓜洲), (4) in Karakhoto, and at the centre close to the Tangut capital (5) in the Baisigou Square stūpa (Chin. Baisigou fangta 拜寺溝方塔), ${ }^{17}$ and (6) in the Hongfo stūpa (Chin. Hongfo ta 宏佛塔) ${ }^{18}$ (for the location of the six sites in the Tangut Empire see map 10.1).

In the following, I focus on depictions of two popular cults in the Tangut Empire at these sites, namely Ușnīṣavijayā, as an example of transmissions of the so-called Outer Tantras according to the Tibetan doxographical system, and Cakrasamuvara and Vajravārāhī, as an example of transmissions of the Inner Tantras or Anuttarayogatantras, both transmissions linked to Tibetan masters and Tangut imperial patronage.

16 The Tangut capital was renamed a few times and appears in sources as Xingzhou (興州), Xingqing (興慶) and Zhongxing (中興). For a discussion of the renaming of the capital see: Ruth W. Dunnell, "Naming the Tangut Capital: Xingqing/Zhongxing and Related Matters," Bulletin of Sung and Yüan Studies 21 (1989): 52-66. Character and Tradition of Ningxia's Tangut Stupas," Orientations 27.4 (1996): 59, fig. 8. 
The starting point of my interest in Tantric visual art in Eastern Central Asia was the Mogao Caves. When the Tanguts conquered Dunhuang some time in the first half of the nth century, ${ }^{19}$ the site had already seen around 700 years of patronage by various imperial and local rulers. Although an important site historically, for the Tanguts Dunhuang was an outpost at the western-most border of their territory. Even so, it was a jewel of the highest Buddhist prestige and of international renown. In fact, Tangut patronage of Buddhism in Dunhuang eventually played an important role in the acceptance and submission of the local community to their authority. ${ }^{20}$ Mogao Cave 465 , as the sole Tantric Buddhist cave in the cave complex, complete with an elaborate iconographic programme related to the Anuttarayogatantras, has been a riddle to scholars (fig. 10.1). ${ }^{21}$

In recent Chinese research, attempting to place the cave in its cultural and historical context, the most important advances were made by Xie Jisheng 22 and by the young Chinese scholar Ruan Li. Ruan Li identified all the main deities and suggested that the cave is related to the Tibetan Kagyü tradition active in the Tangut Empire, with a focus on the deities Cakrasaṃvara and Vajravārāhī, who are depicted on the main wall facing the entrance. Ruan even suggested that a statue of Vajravārāhī might have been placed on the central altar (which originally had five tiers), ${ }^{23}$ given the popularity of that cult in the Tangut Empire. What is most striking is the fact that despite the exquisitely painted murals in an accurately excavated cave, featuring a well-planned iconographic programme, no donor figures are depicted in the cave. This is unusual in Dunhuang because the previous rulers of Dunhuang, the Guiyijun (851-1036? 歸義

19 Dunnell, The Great State of White and High, 193 fn. 59. Ruth Dunnell reviewed the Chinese secondary sources, with the result that most Song Chinese sources date the Tangut conquest of Dunhuang to the year 1036, however, with a rather loose reign until much later in the nth century.

20 Ibid., 63.

21 For detailed images of this cave see Yang Xiong 楊雄 and Wu Jian 吳健, eds., Dunhuang shiku yishu. Mogao ku di siliuwu ku (Yuan) 敦煌石窟藝術。莫高窟第四六五 窟（元）[Art from the Caves of Dunhuang. Mogao Cave 465 (Yuan)] (Nanjing: Jiansu meishu chubanshe, 1996). An image of the main chamber of the cave appears on plate 3 (p. 34).

22 Xie Jisheng 谢继胜, “Mogao ku di 465 ku bihua hua yu Xixia kao 莫高窟第465 窟壁画 绘于西夏考 [Study of the Wall Paintings in Mogao Cave 465 from Tangut Times]," Zhongguo zangxue 中国藏学 [China's Tibetology] 2 (2003): 69-79.

23 Ruan Li 阮丽, “Mogao ku di 465 ku mandaluo zaikao 莫高窟第465窟曼茶罗再考 [Study of the mandala in Mogao Cave 465]," Gugong bowuyuan yuankan 故宮博物院院 刊 [Journal of the Museum of the Forbidden City] 168 (2013): 61-83. 


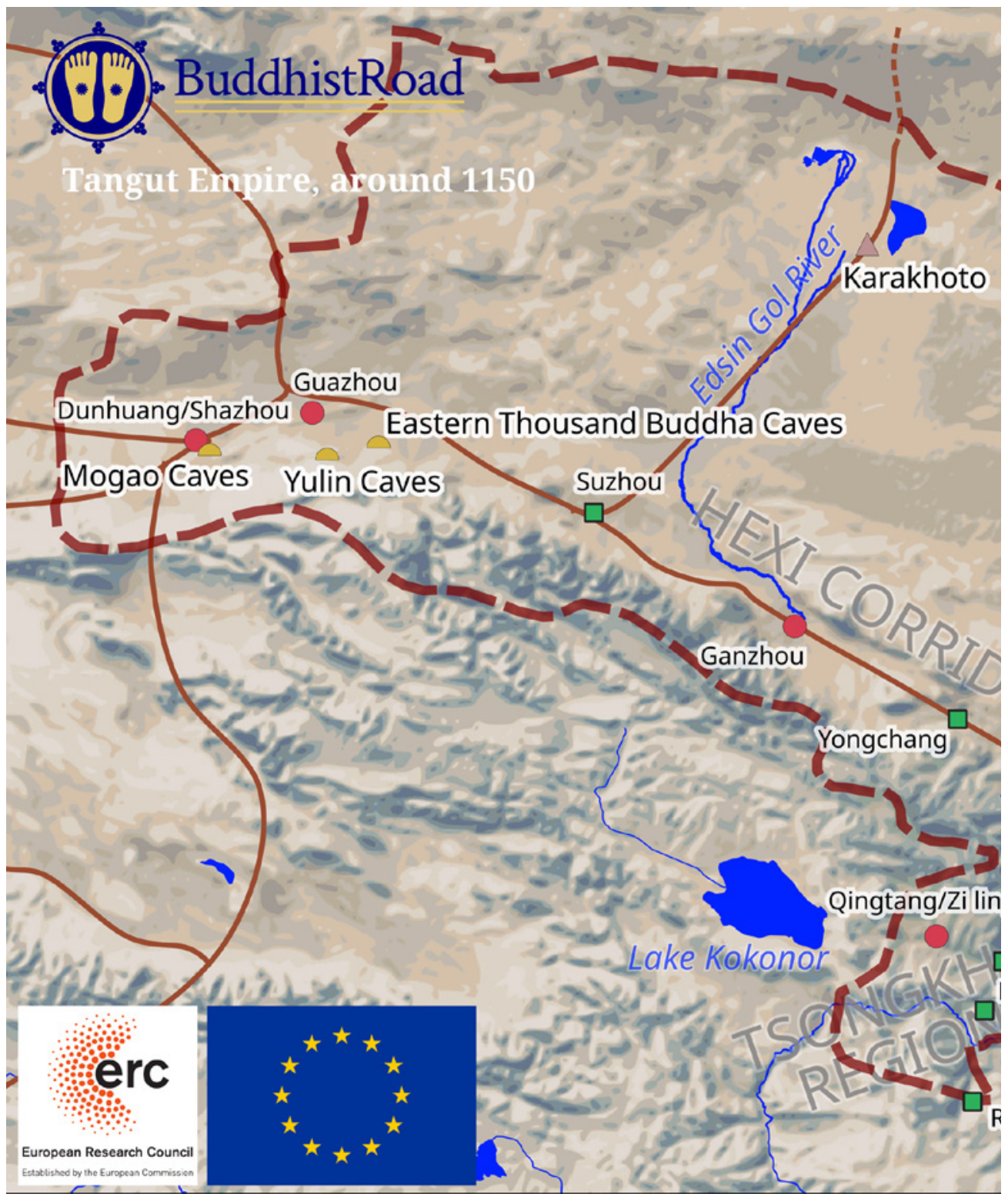

MAP 10.1 Territory of Tangut Empire around 1150.

(C) ERC PROJECT BUDDHISTROAD. THE MAP WAS PREPARED BY JÜRGEN SCHÖRFLINGER. 


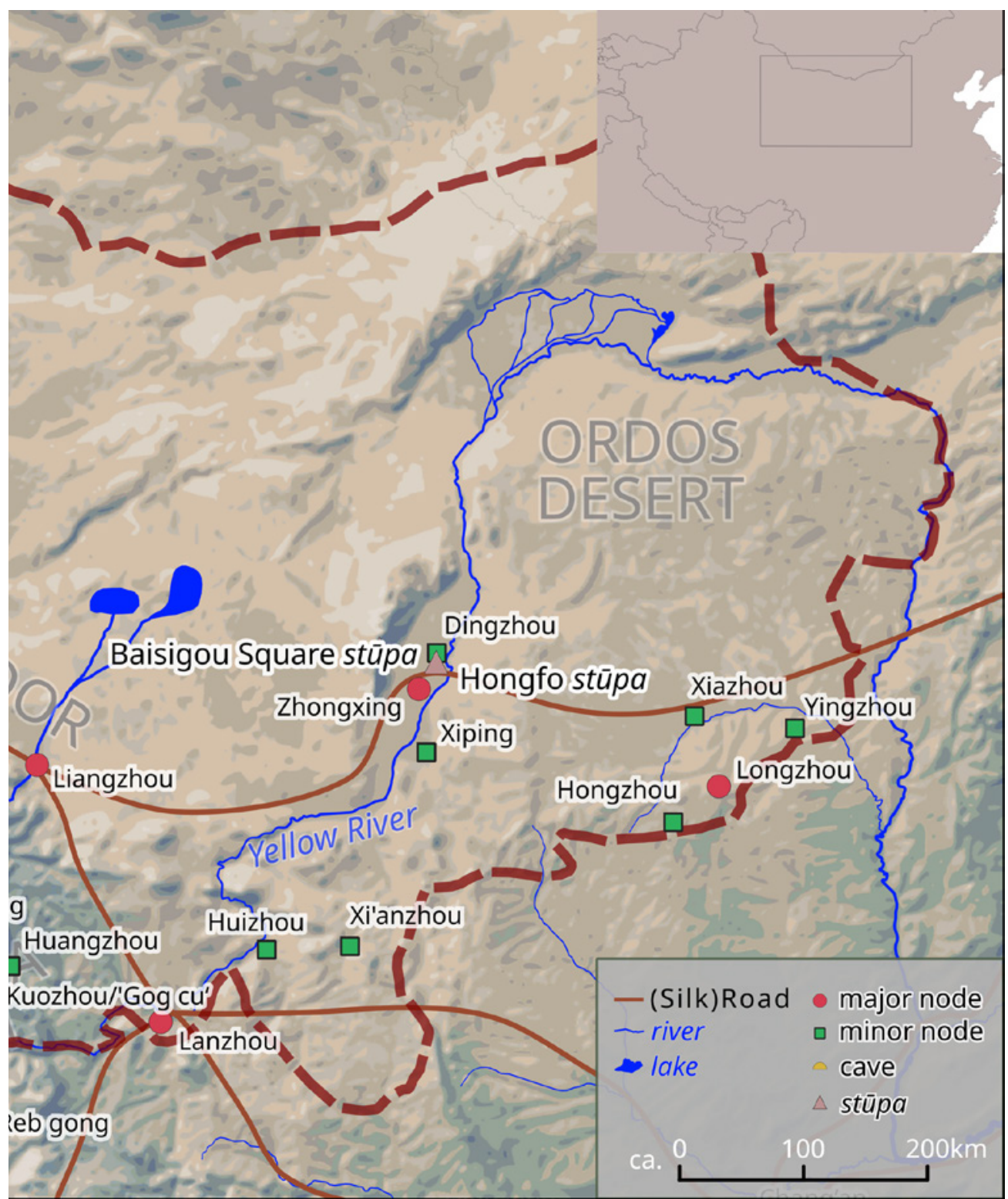




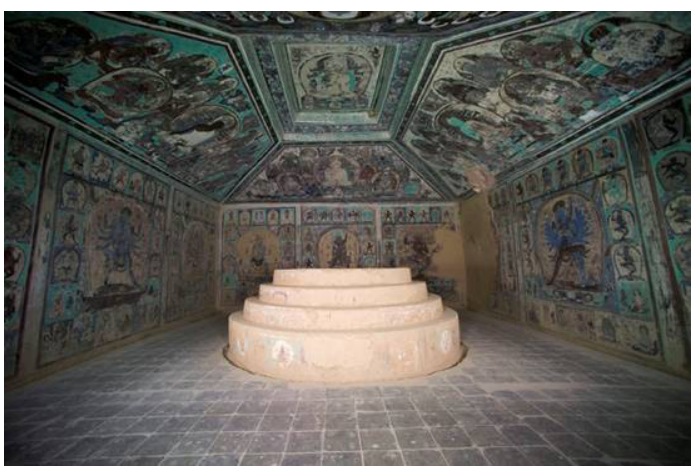

FIGURE 10.1

Mogao Cave 465, Dunhuang, late 12th c. (?).

YANG XIONG AND WU JIAN, DUNHUANG SHIKU YISHU. MOGAO KU DI SILIUWU KU $(Y U A N)(1996)$, PLATE 3 (P. 34)

軍, Return-to-Allegiance Army), followed a general trend in the region of depicting life-sized donor figures, for example as in Mogao Cave 61. ${ }^{24}$ It is also unusal in the context of Tangut productions at other sides, where donor figures are typically depicted (though not in life-size), as I demonstrate below.

Despite lacking donor figures, I suggest that Mogao Cave 465, with its deliberate Tantric iconography programme, was most likely created under Tangut imperial patronage in the late 12th c., either patronised by Renzong himself or by his son and immediate successor, Huanzong (r. 1193-1206, 桓宗). I assert the cave as the culmination of imperial patronage of Tantric visual art in the Tangut Empire, around the late 12th to early 13th centuries, a period leading to the eventual Mongol conquest of the Tangut Empire. Since there is no immediate evidence for my hypothesis found within the cave itself, I employ the following method of deduction by looking at the larger context of the cave and the production of other Tantric Tangut sites from around the same time. I make an excursion to the other sites mentioned above before returning to Mogao Cave 465 at the end of this chapter.

The nearby Yulin Caves in Anxi (for the location of the site see map 10.1) were also situated in the Western periphery of the Tangut territory. As we know from Chinese scholarship, Yulin Caves 2, 3, and 29 were created and renovated under Tangut rule. In Cave 29, presumably from 1193, the year of Emperor Renzong's death, we have a Tangut inscription which identifies the donor portraits as high-ranking Tangut military officers with titles, namely the "acting Shazhou [that is, Dunhuang] Army Supervisor Zhao Mayu" and the "Guazhou Controller General Zhou Zuyu." ${ }^{25}$

$24 \quad$ For images of 1oth century life-size donor figures in Mogao Cave 61 see Dunhuang wenwu yanjiu suo, Dunhuang Mogao ku, vol. 5, plates 77 and 79 .

25 Linrothe, "Xia Renzong and the Patronage of Tangut Buddhist Art," 115, fig. 3; Rob Linrothe, "Ushnīshavijayā and the Tangut Cult of the Stūpa at Yü-lin Cave 3," National Palace Museum Bulletin 31.4-5 (1996): 1-25. Moreover, Yulin Cave 29 depicts a master identified 
In Yulin Cave 3, on the Southern wall in the Eastern section, we find a depiction of an Ușnīṣavijayā maṇdala (fig. 10.2). According to Rob Linrothe, the transmission likely came through Tibetan artisans, as a personified cult of Ușnīṣavijayā did not exit in much of East Asia at this time. ${ }^{26}$ Ușnīṣavijayā is known as a Tantric deity related to long-life and protection (also for a favourable rebirth). She sits within the womb of a stüpa representing the Buddha body. The most remarkable feature of this mural is its central depiction of a royal figure, maybe a donor, at the divinity's feet on the steps of the stüpa. Linrothe suggests that here Emperor Renzong has positioned himself (although not in life-size) in this very central position as an imperial patron in the sacred narrative honoring the deity as an initiated meditator. Linrothe further identifies a rite related to Ușnịșavijayā that was practiced in antiquity in India on the occasion of a person's sixtieth birthday, called the Ugraratha rite. ${ }^{27}$ Renzong celebrated his sixtieth anniversary on a large scale in 1184, producing and distributing 51,00o painted and printed banners, according to a dedicatory inscription from that year. ${ }^{28}$ According to Linrothe, a printed Ușnīṣavijayā dhārañi found in the Square stūpa of Baisigou, close to the Tangut capital (for the location of the site see map 10.1), might be one such example of a printed Ușnīṣavijayā dhāraṇi produced for Renzong's birthday (?). ${ }^{29}$ In fact, another Chinese fragment found within the stüpa was a handscroll that he and Ruth Dunnell date to the year 1180, making it not unlikely that these objects were placed in the stüpa for the 1184 celebrations. ${ }^{30}$

I raise another argument in support of Linrothe's hypothesis that Emperor Renzong is depicted in the central position of the Ușnịșavijayā maṇdala in Yulin Cave 3, as both a royal patron and a private person, or as a meditator. In two other sites, namely in the Eastern Thousand Buddha Caves of Guazhou, and in material from the Karakhoto Collection (for the location of these sites see map 10.1), we find images of Ușnīṣavijayā, albeit stylistically somewhat

in an inscription as Zhenyi State Preceptor. A certain Zhengyi, also known as Jingjie, is mentioned in an 1189 imperial preface. However, Shi Jinbo notes that it is not clear whether both persons are identical or not. Cf. Shi Jinbo 史金波, Xixia fojiao shilüe 西夏佛教史 略 [A Concise History of Tangut Buddhism] (Yinchuan: Ningxia renmin chuban she, 1988), 302. See also Ruth W. Dunnell, "Translating History from Tangut Buddhist Texts," Asia Major 22.1 (2009): 51 fn. 28 and 77 fn. 110.

26 Linrothe, "Xia Renzong and the Patronage of Tangut Buddhist Art," 98-103. The image of the Ușnīṣavijayā maṇdala from Yulin Cave 3 is published in: Dunhuang yanjiuyuan 敦煌 研究院, ed., Zhongguo shiku. Anxi Yulin ku 中國石窟。安西榆林窟 [Caves of China. Yulin Caves in Anxi] (Beijing: Wenwu chubanshe, 1997), plate 153.

27 Linrothe, "Xia Renzong and the Patronage of Tangut Buddhist Art," 103-105.

28 Shi Jinbo, Xixia fojiao shilüe, 40.

29 For the image of this printed Ușnịșavijayā dhāraṇī see Linrothe, "Xia Renzong and the Patronage of Tangut Buddhist Art," 115, fig. 3 .

30 Linrothe, "Xia Renzong and the Patronage of Tangut Buddhist Art," 96-97. 


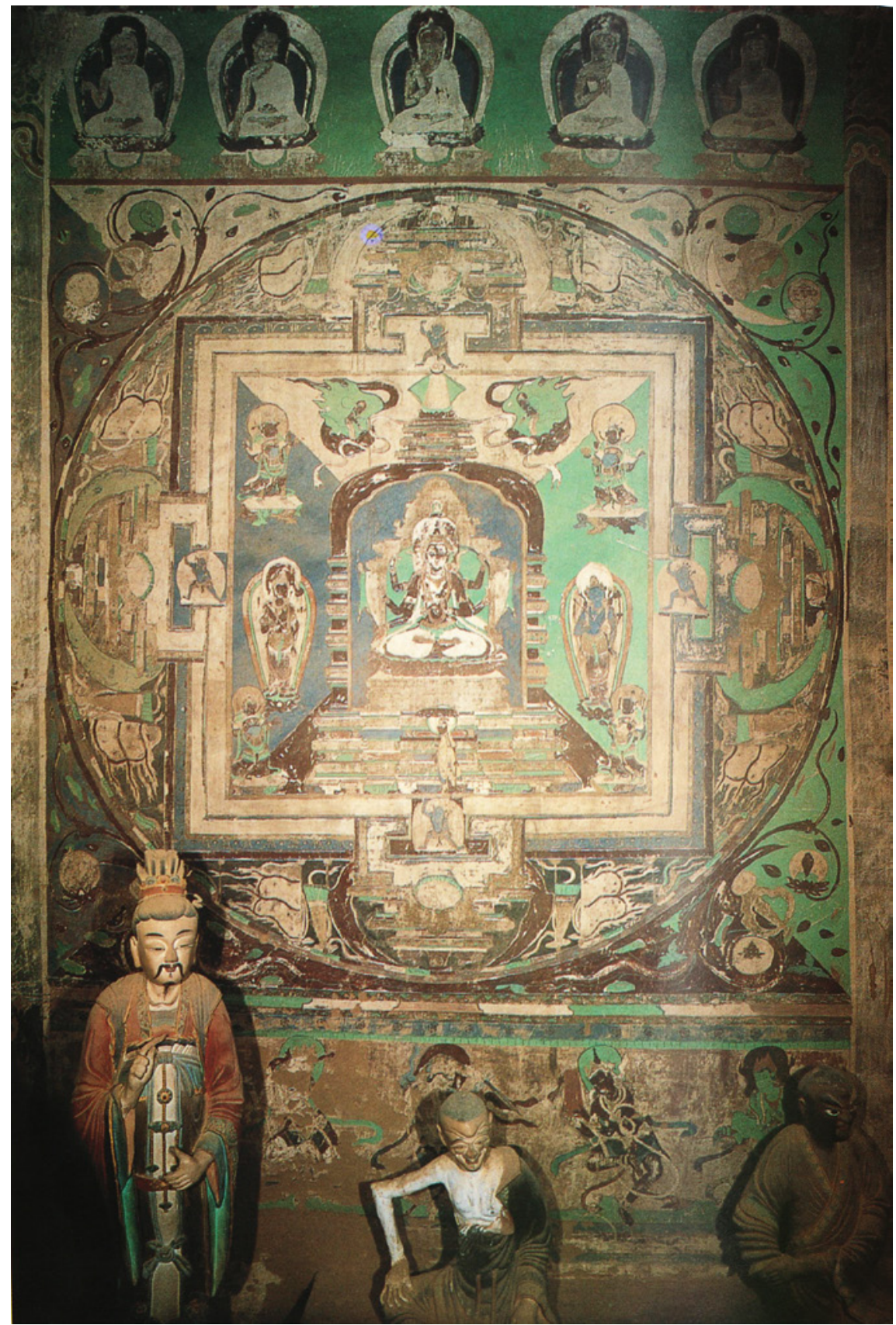

FIGURE 10.2 Mural of Ușnīịavijayā maṇdala. Yulin Cave 3, Southern wall, Eastern section, late 12 th c. (?). DUNHUANG YANJIU YUAN, ED., ZHONGGUO SHIKU. ANXI YULIN KU (1997), PLATE 153 
different from the Yulin Cave 3. If we compare the position of the patron figure as it appears in Yulin Cave 3 with what we find in the very same position in the depiction from Guazhou, it is apparent that the position of the donor figure in Yulin Cave 3 must have been deliberately chosen. In the mural in the Eastern Thousand Buddha Cave 2, in the position below Ușnīṣavijayā, on the steps to the stüpa, one can see her seed syllable in siddham script (fig. 10.3). ${ }^{31}$ The seed syllable is the essence of the deity, here placed in a very prominent position. Even more striking is the comparision with the Ușnịșavijayā maṇdala on the wooden panel x2406 from Karakhoto (fig. 10.4). ${ }^{32}$ Here, the donor figure is depicted in the lower right corner of the panel, outside the sacred mandala space (more about this donor further below). In the central position below Ușnīṣavijayā, on the steps of the stūpa, is what is most likely the representation of a Tantric initiate, maybe an Indian, kneeling in veneration to the deity, with a Tantric crown on his head, and holding an umbrella with both hands.

I suggest that the depiction in Yulin Cave 3 took such an arrangement as its inspiration, with minor but important changes: In the Yulin depiction, the patron figure also holds an umbrella, but he is standing not kneeling (maybe bending slightly forward with the upper part of his body). We may assume that only the emperor himself would be in a position to firstly commission his own local creation and place himself as a patron within the mandala of the deity; secondly, choose the central position where the essence of the deity, or an initiate in the tradition, is depicted; and thirdly, take the liberty of not kneeling in front of the deity in such a prominent place within the sacred narrative frame. It is easy to imagine that no one else could have taken the privilege to do so! If the Ușnișavijayā maṇdala in Yulin Cave 3 was produced on the occasion of Rengzong's 6oth anniversary celebration in 1184, it was probably done with the aspiration for a long and protected life (in fact, he had another nine years to live). From this evidence, I infer that the Tangut ruler, most likely Renzong, not only portrayed himself as a pious supporter of (Tantric) Buddhism, in the

$3^{1} \quad$ The image of Uș̣ịșavijayā in the Eastern Thousand Buddha Cave 2 in Guazhou is published in: Zhang Baoxi 张宝胥, Guazhou Dong qianfodong Xixia shikuyishu 瓜洲東千佛 洞西夏石窟藝術 [The Art of the Tangut Caves in the Eastern Buddhas Caves in Guazhou] (Beijing: Xuyuan chuban she, 2012), plates 6 (p. 105) and 6 (2-1) (p. 106); a sketch of Cave 2 in found on p. 16, fig. 14.

32 The image of the Uṣnīșavijayā maṇdala on the wooden panel x2406 from Karakhoto is published in: The State Hermitage Museum, Russia, Northwest University for Nationalities, and Shanghai Chinese Classics Publishing House, ed., Khara-Khoto Art Relics Collected in the State Hermitage Museum of Russia, vol. 2 (Shanghai: Shanghai Chinese Classics Publishing House, 2012), plate 125. Another almost identical image (x2407) is found on plate 126. Moreover, the images can also be downloaded on the museum website: <https://www.hermitagemuseum.org/wps/portal/hermitage/digital-collection/25.+arch aeological+artifacts/477210> and <https://www.hermitagemuseum.org/wps/portal/her mitage/digital-collection/25.+archaeological+artifacts/477211>, accessed August 30, 2018. 


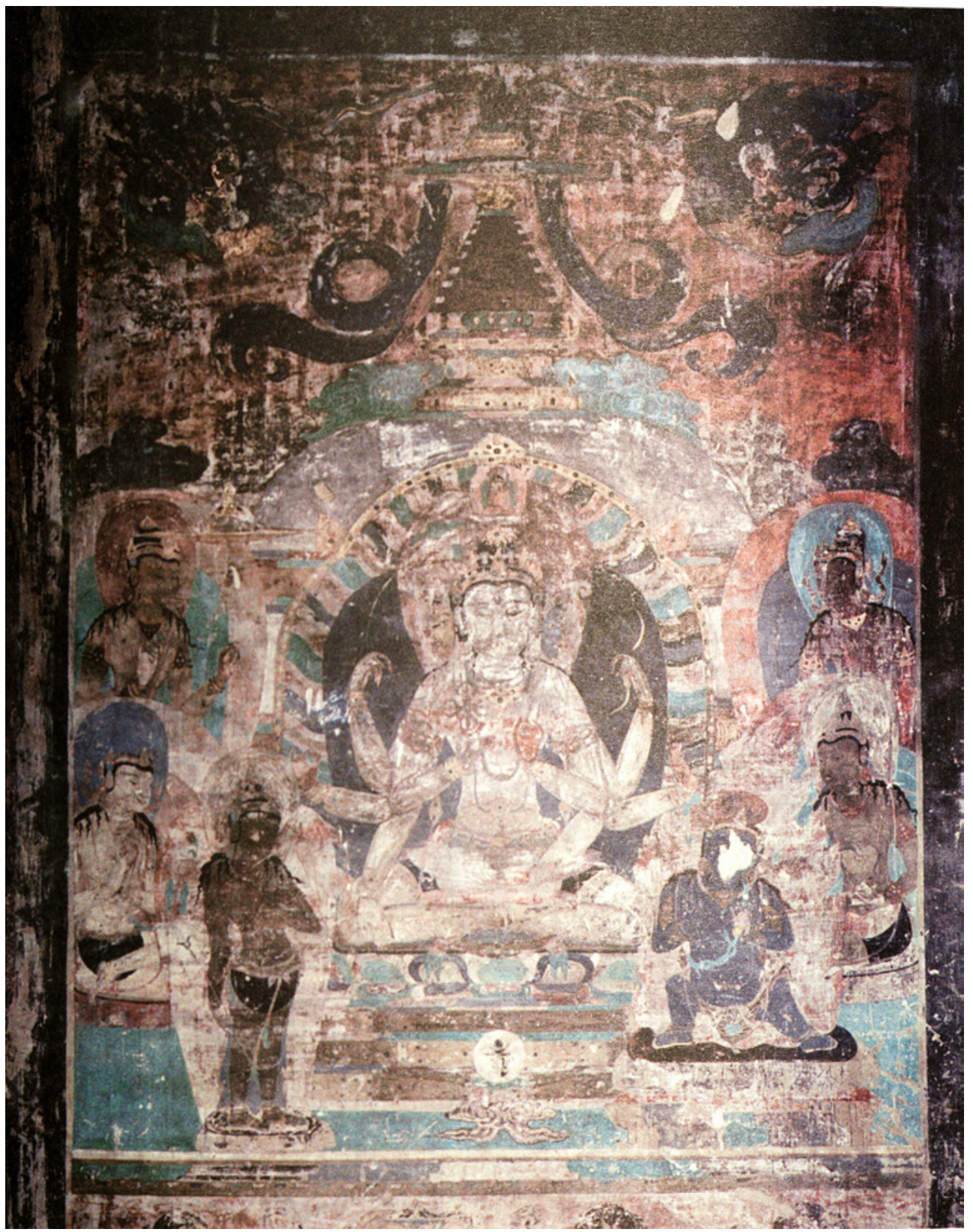

FIGURE 10.3 Mural of Ușṇiṣavijayā. Eastern Thousand Buddha Cave 2, Guazhou. ZHANG BAOXI, GUAZHOU DONG QIANFODONG XIXIA SHIKU YISHU (2012), PLATE 6 (P. 105) 


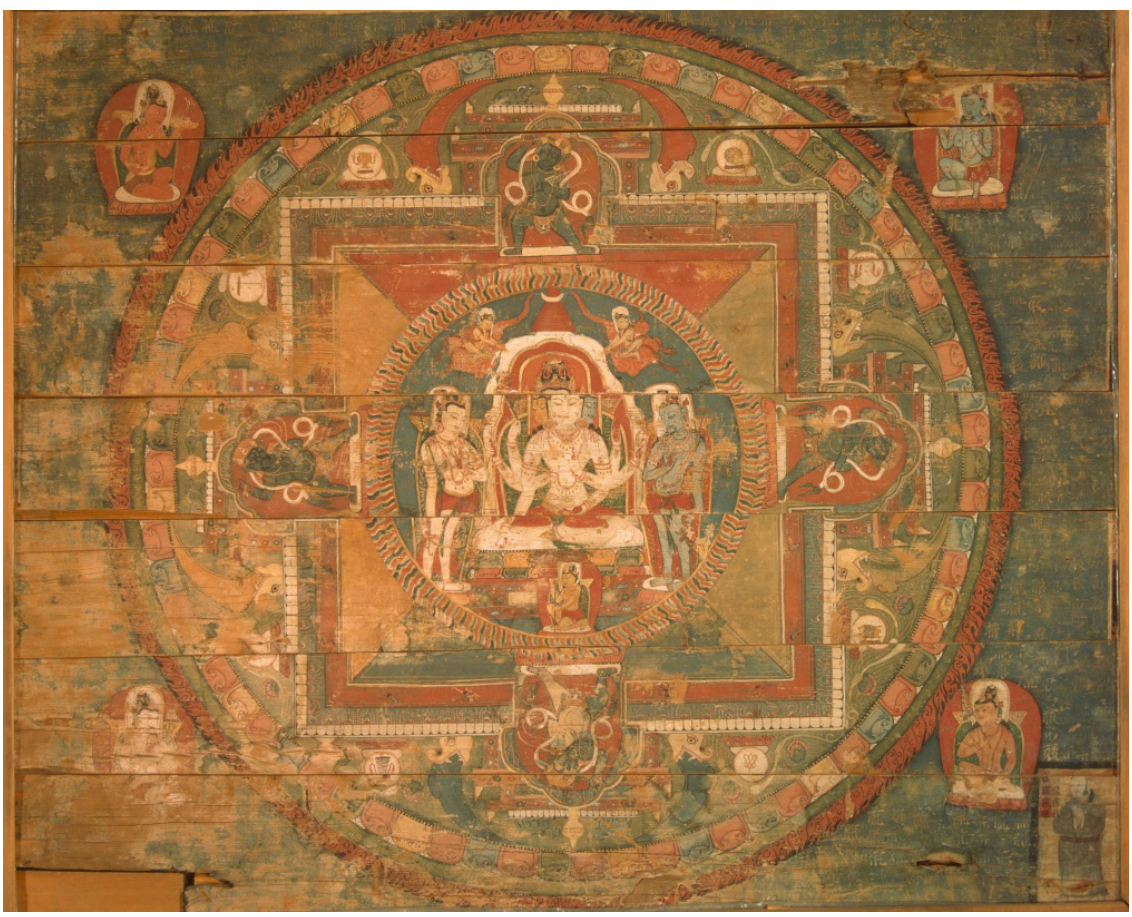

FIGURE 10.4 Wooden panel of Ușnīṣavijayā maṇdala. Karakhoto, late 12th c. (?). X2406, The STATE hermitage MUSEUm, St. PETERSBURG

manner of an Aśokan-style Buddhist ruler, but also as an initiate with a very private soteriological aspiration.

Moreover, the two almost identical Karakhoto panels (x2406 (fig. 10.4) and x2407) of the Uṣnīṣavijayā maṇdala show that Tantric practices seem to have been wide-spread among the Tangut nobility (according to the garments and headdress of the donor figures in the lower right corners of the wooden panels). They depict a male and a female donor, who certainly commissioned what appears to be a standard Ușṇīṣavijayā depiction (figs. 10.5 and 10.6). Kirill Solonin kindly helped to decipher the Tangut inscriptions in the painting. The male donor can be identified as "The one who took the vow" (Tang. Yeli zi śiã), the last three characters appear to be a nickname or 'styled name,' rendered in Chinese as 'Songbai shan' (松柏山). The female person is called Liang (梁) and made the aspiration that another person may attain true liberation. ${ }^{33}$

Let me move on and link another piece of evidence to my argument that Tangut imperial rulers, particularly Renzong, were rather strong and eager supporters of creating Tantric sacred spaces within their realm. In Karakhoto, also

Thanks to Kirill Solonin for identifying the Tangut inscription for me. 

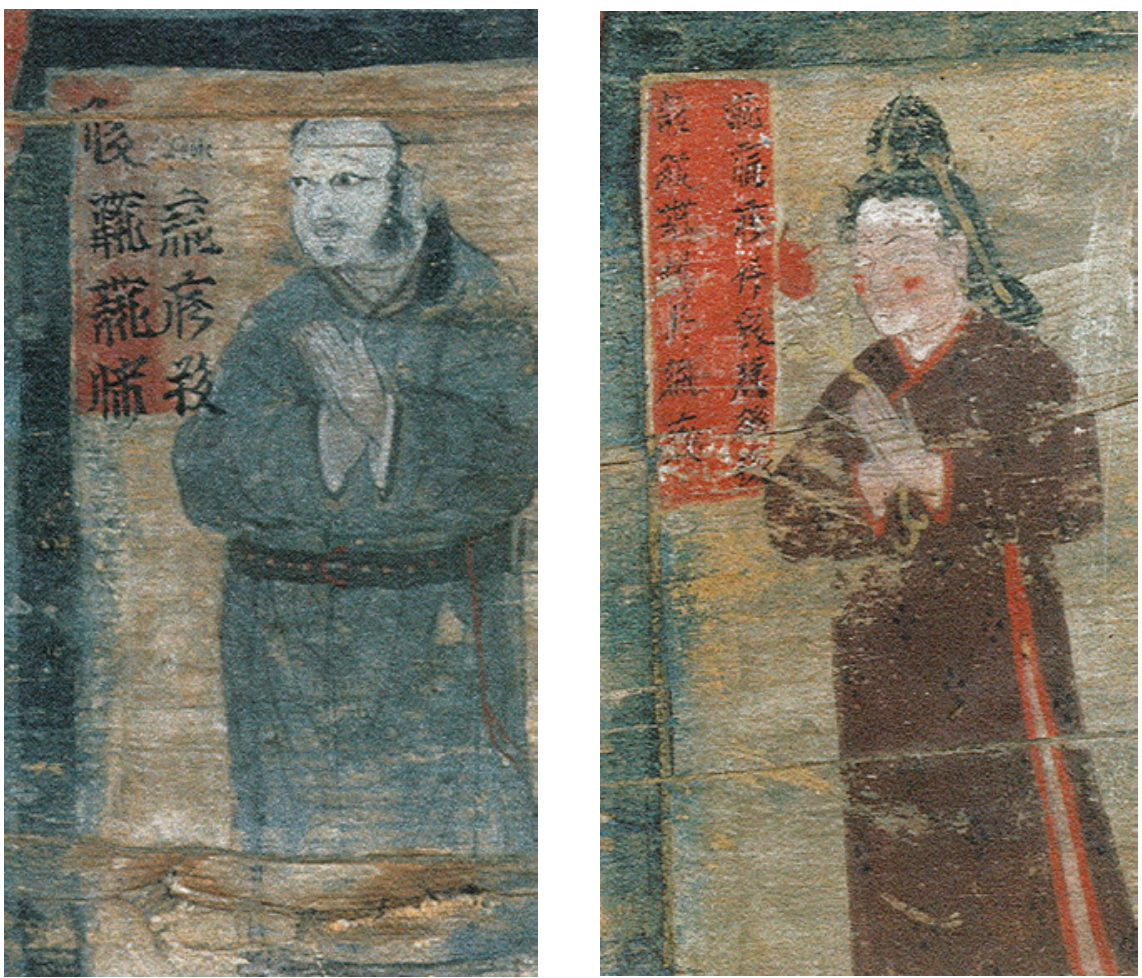

FIGURES 10.5-10.6 Male and female donors in lower right corner of wooden panels of Ușnīṣavijayā maṇdala. Karakhoto, late 12th c. (?). Details of x2406 (fig. 10.4, male donor) and X2407 (female donor).

THE STATE HeRMitage MUSEUM, St. PETERSBURG

an outpost of the Tangut Empire (for the location of the site see map 10.1), stüpas were erected and filled with various Buddhist materials (with printed texts and manuscripts in Chinese, Tangut and Tibetan and pieces of visual art). These Buddhist monuments appear as markers on the Tangut borders and might be understood as rendering protection to Tangut territory.

The thangka x240o from the Karakhoto Collection ${ }^{34}$ provides extraordinary evidence of the intimate relationship between a Buddhist master, sitting

34 The image of the portrait of the Buddhist master with the imperial couple ( $\mathrm{x} 2400)$ from Karakhoto is published in: The State Hermitage Museum, Northwest University for Nationalities, and Shanghai Chinese Classics Publishing House, Khara-Khoto Art Relics Collected in the State Hermitage Museum of Russia, plate 173. Moreover, the images can also be downloaded on the museum website: <https://www.hermitagemuseum.org/wps/por tal/hermitage/digital-collection/25.+archaeological+artifacts/477204>. 


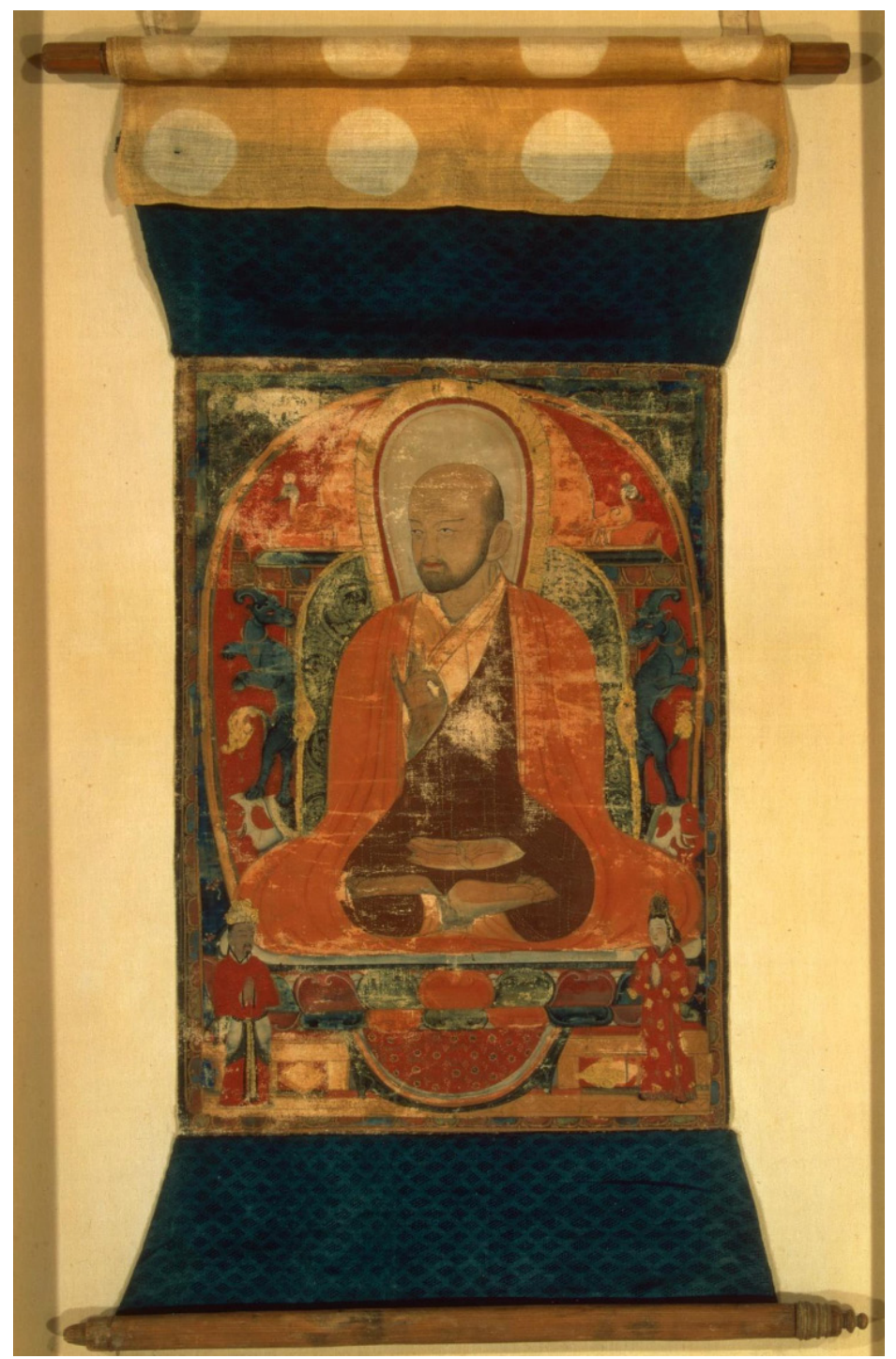

FIGURE 10.7 Thangka with a portrait of a Buddhist master with imperial couple. Karakhoto, late 12th c. (?).

X2400, THE STATE HERMitAgE MUSEUM, ST. PETERSBURG

in meditation posture with the gesture of teaching, and a couple from the imperial family, both with hands held in veneration (fig. 10.7). A number of scholars have suggested that the depicted master might be either a State Preceptor (Chin. guoshi 國師) or an Imperial Preceptor. Kira Samossiuk suggests that the date of the thangka should not be earlier than the 117os, and sees in the donor couple a young ruler with his young wife, thus ruling out that it could be 


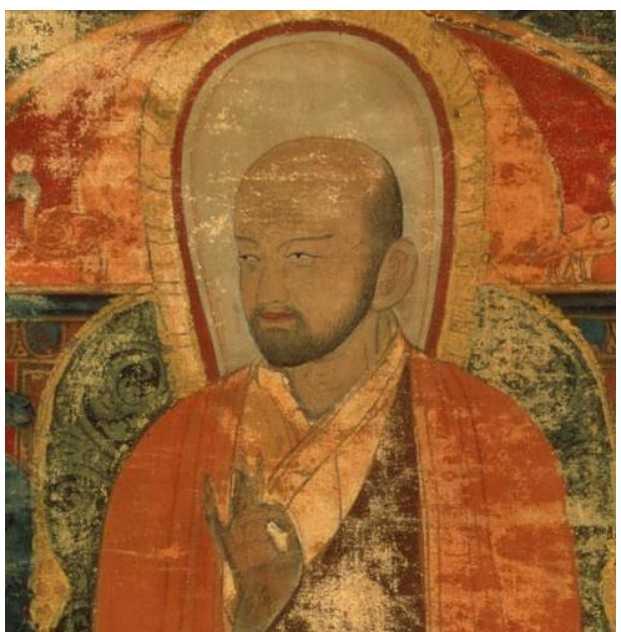

FIGURE 10.8

Detail of the portrait of a Buddhist master (figure 10.7). Karakhoto, late 12th c. (?). X2400, THE STATE HERMITAGE

MUSEUM, ST. PETERSBURG

Renzong, who was already old by 1170. She suggests it more likely depicts one of his successors, either Huanzong (r. 1194-1206, 桓宗) or Xiangzong (r. 1206-1211, 襄宗). ${ }^{35}$ Although it is difficult to judge the actual age of the imperial couple depicted, it is possible to put the master depicted in context with other materials. If we look at the distinct facial features of the Buddhist master in the thangka-his wrinkles on the forehead, particularly his pronounced beardand his outer garment, it is very likely a portrait of a contemporary of the imperial couple (fig. 10.8).

I suggest that this Buddhist master's specialty was the transmission of the Vajravārāhī and Cakrasamvvara cycles, based on his appearance in other Karakhoto thangkas. A master with the same distinct facial features appears in the Karakhoto thangka x2393 of Vajravārāhī (figs. 10.9 and 10.10) and in the Karakhoto thangka x3556 of Cakrasamvara-Vajravārāhī in union (figs. 10.11 and 10.12). ${ }^{36}$ This master, when seen in connection with transmissions of the Anuttarayogatantras, is likely a Tibetan.

35 Kira Samossiuk, "Donors' in the Tangut Painting from Khara-Khoto: Their Meaning and Function," The Tibet Journal 26.3-4 (2001): 173-174.

36 The images of Vajravārāhī (x2393) and Cakrasamvvara-Vajravārāhī in union (x3556) from Karakhoto are published in: The State Hermitage Museum, Northwest University for Nationalities, and Shanghai Chinese Classics Publishing House, Khara-Khoto Art Relics Collected in the State Hermitage Museum of Russia, plates 142 and 132. Moreover, the images can also be downloaded on the museum website: $<$ https://www.hermitagemuseum. $\mathrm{org} / \mathrm{wps} / \mathrm{portal} /$ hermitage/digital-collection/25.+archaeological+artifacts/477197> and: <https://www.hermitagemuseum.org/wps/portal/hermitage/digital-collection/ol.+paint ings/539191>, accessed August 29, 2018. Here an interesting date is provided for x2393: "after 1189-before 1200." 

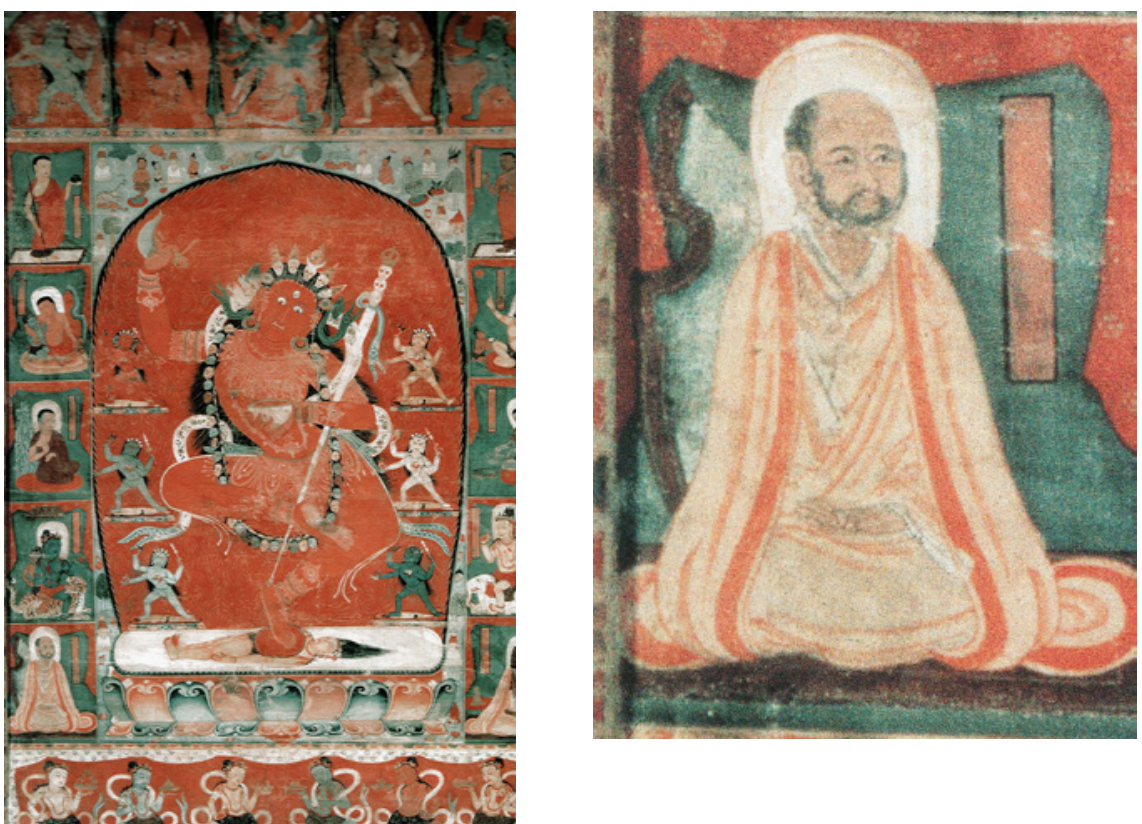

FIGURES 10.9-10.10 Thangka of Vajravārāhī and detail of Buddhist master in lower corner of left register. Karakhoto, late 12th c. (?).

X2393, the State hermitage museum, St. Petersburg
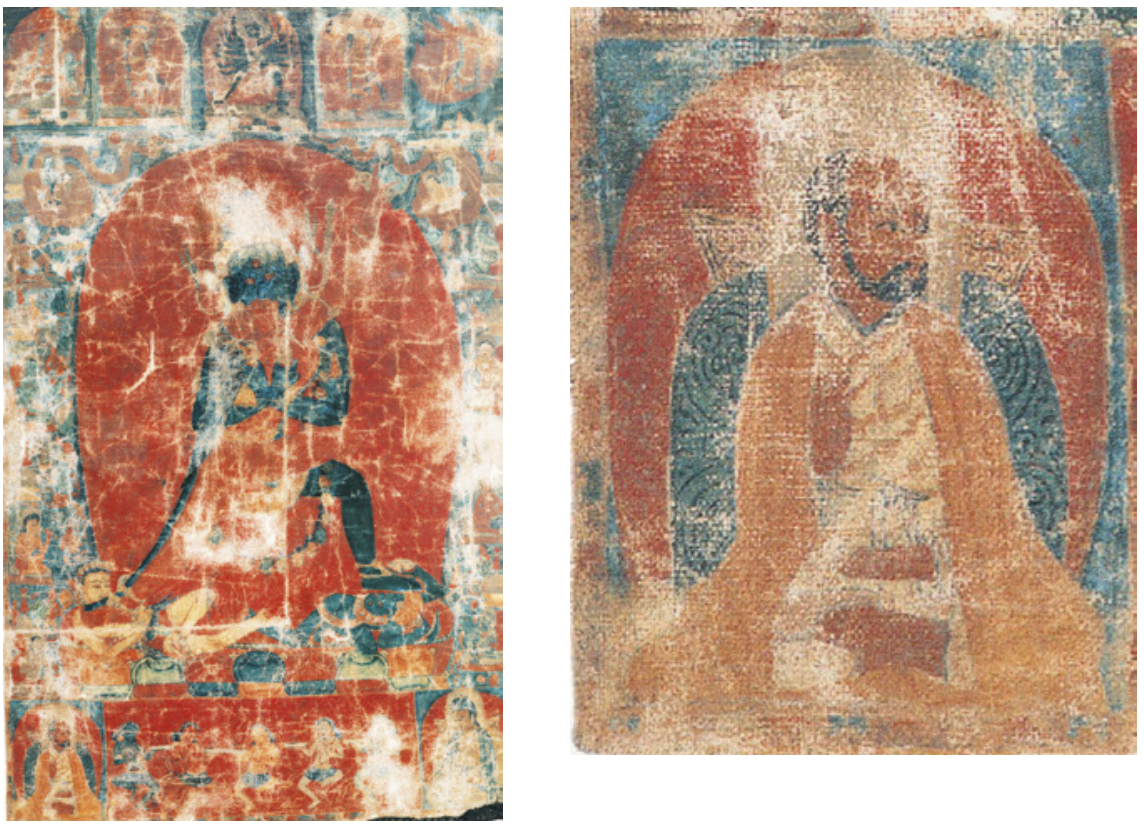

FIGURES 10.11-10.12 Thangka of Cakrasamvara-Vajravārāhī in union and detail of Buddhist master in lower left corner. Karakhoto, late 12th c. (?).

X3556, THE STATE HERMITAGE MUSEUM, ST. PETERSBURG 

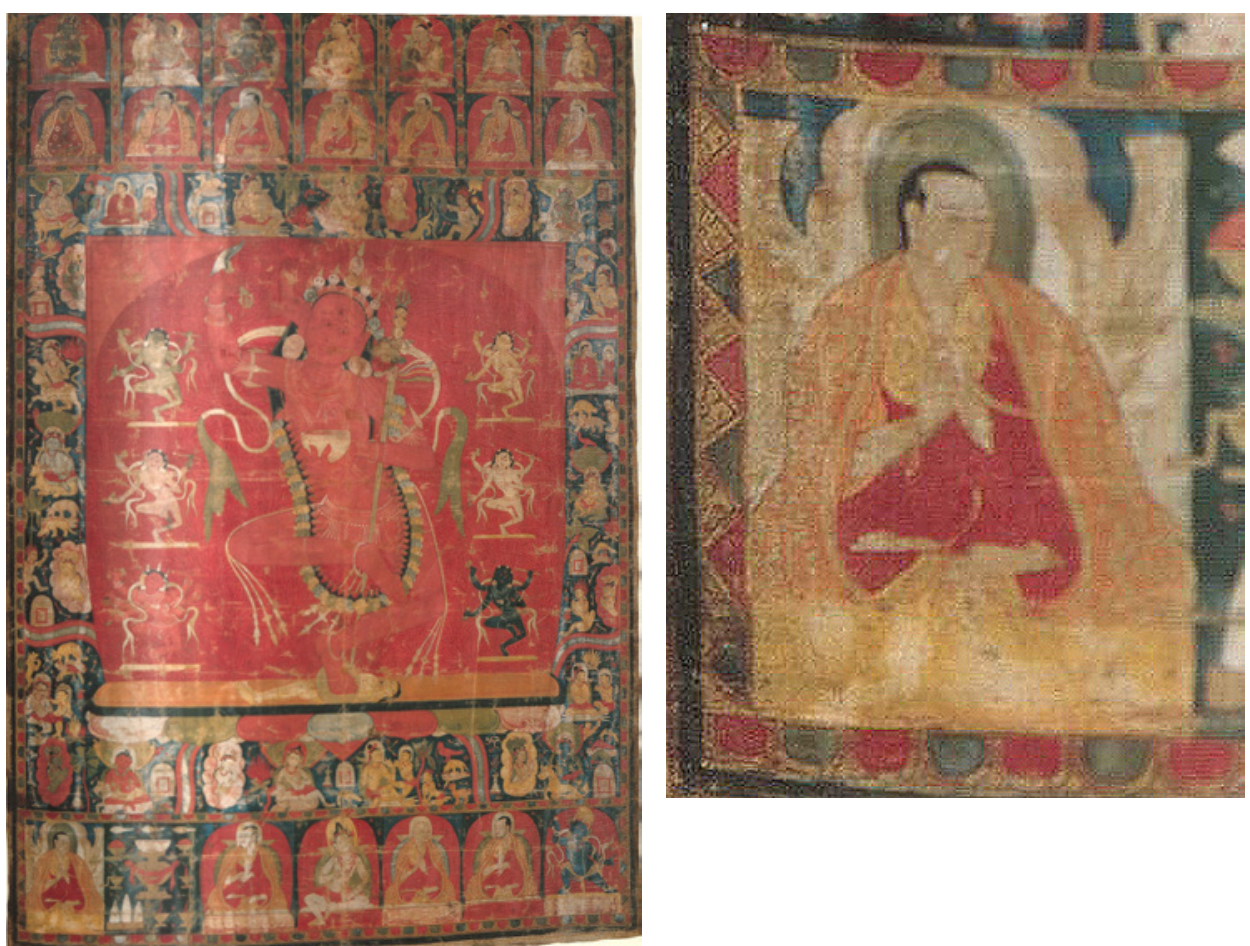

FIGURES 10.13-10.14 Thangka of Vajravārāhī and detail of Buddhist master in lower left corner. Western Trans-Himalaya, anonymous collection.

DEBORAH E. KLIMBURG-SALTER, THE SILK ROUTE AND THE DIAMOND PATH (1982), PLATE 112

In fact, Tibetan masters with a similar distinct outer garment are found in a Vajravārāhī thangka from the Western Transhimalayas identified by Deborah Klimburg-Salter (figs. 10.13 and 10.14), ${ }^{37}$ and more importantly for immediate comparision, at Guazhou in the Eastern Thousand Buddha Cave 4, in a central niche directly opposite the entrance (fig. 10.15). ${ }^{38}$ There is a remarkable stylistic similarity in the depiction of the pleats of the outer garment, and the way the rope is wrapped around the legs in both depictions. Unfortunately, the Guazhou mural is rather damaged and the facial features are no longer discernible.

37 The Vajravārāhī thangka from the Western Transhimalayas is published in: Deborah Klimburg-Salter, The Silk Route and the Diamond Path: Esoteric Buddhist Art on the TransHimalayan Trade Routes (Los Angeles: UCLA Art Council, 1982), plate 112.

38 An image of the master in Eastern Thousand Buddha Cave 4 in Guazhou is published in: Zhang Baoxi, Guazhou Dong qianfodong Xixia shiku yishu, plate 35 (p. 184). An image of the niche in Cave 4 is published on p. 183, fig. 34 and a sketch of the cave on p. 16, fig. 15 . 


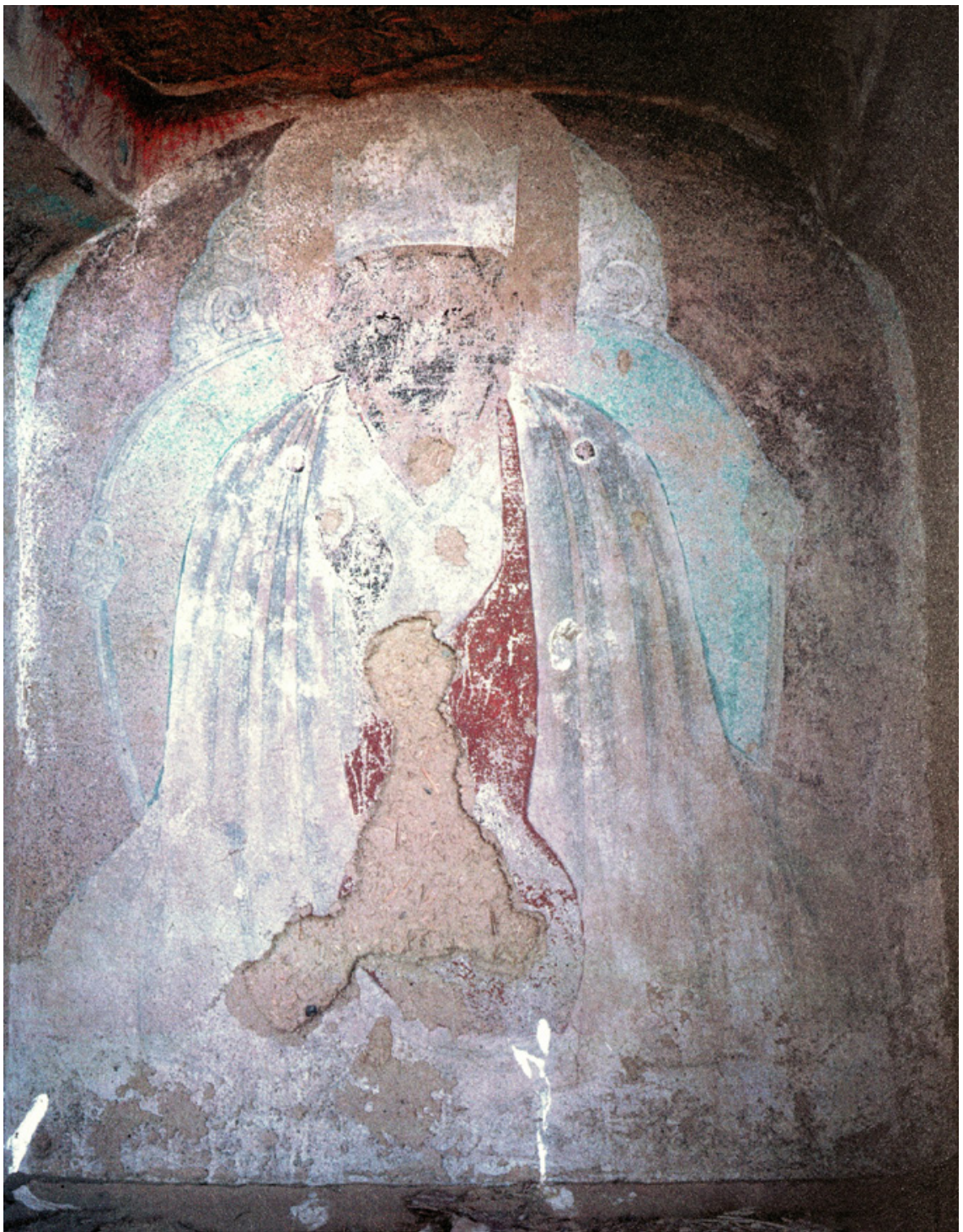

FIGURE 10.15 Mural of portrait of Buddhist master with white hat. Eastern Thousand Buddha Cave 4, Guazhou.

ZHANG BAOXI, GUAZHOU DONG QIANFODONG XIXIA SHIKU YISHU, PLATE 35 (P. 184) 


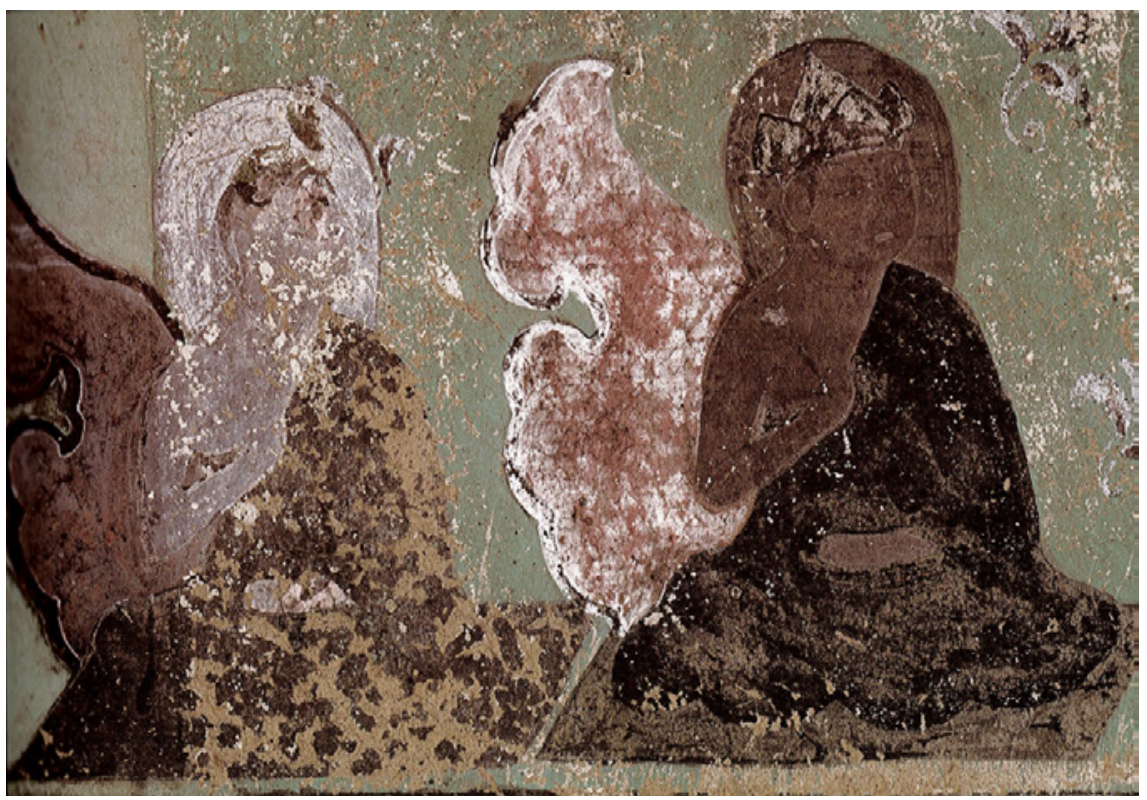

FIGURE 10.16 Buddhist master with white hat. Mogao Cave 465, Eastern wall, above entrance in main chamber, Dunhuang, late 12th c. (?).

YANG XIONG AND WU JIAN, DUNHUANG SHIKU YISHU. MOGAO KU DI SILIUWU KU (YUAN), PLATE 117 (P. 145)

However, what is striking is the fact that here, the depicted master is wearing a white hat - the same type of white hat which appears in some of the other Tantric sites mentioned previously, both in murals and thangkas, and most importantly, in Mogao Cave 465 in Dunhuang (fig. 10.16), 39 the cave where this discussion began. The white hat is similar to a Tantric crown which is sometimes worn for initiations ${ }^{40}$ - there are further examples of this crown from Dunhuang (figs. 10.17 and 10.18) and Karakhoto (figs. 10.19 and 10.20).

Let me return to the most important evidence for my argument, namely the Karakhoto thangka with the portrait of the Buddhist master and the imperial donor couple (see fig. 10.7), and put forth the following thesis: I suggest that here we might have a depiction of the Tibetan Kagyü master Tsangpopa $(+1218$,

39 Images of Tantric masters with a white hat in Mogao Cave 465 are also published in:Yang Xiong and Wu Jian, Dunhuang shiku yishu. Mogao ku di siliuwu ku (Yuan), plates 105 (p. 134, Northern wall, central section) and 117 (p. 145, Eastern wall, above entrance).

40 Thanks to an exchange with Matthew Kapstein in December 2017 in Paris, I agree with him that this white hat must be a ceremonial hat worn by Tantric masters on special occasions, rather than a Padmasambhava hat, as suggested by Xie Jisheng. Xie Jisheng, "Mogao ku di 465 ku bihua hua yu Xixia kao." 


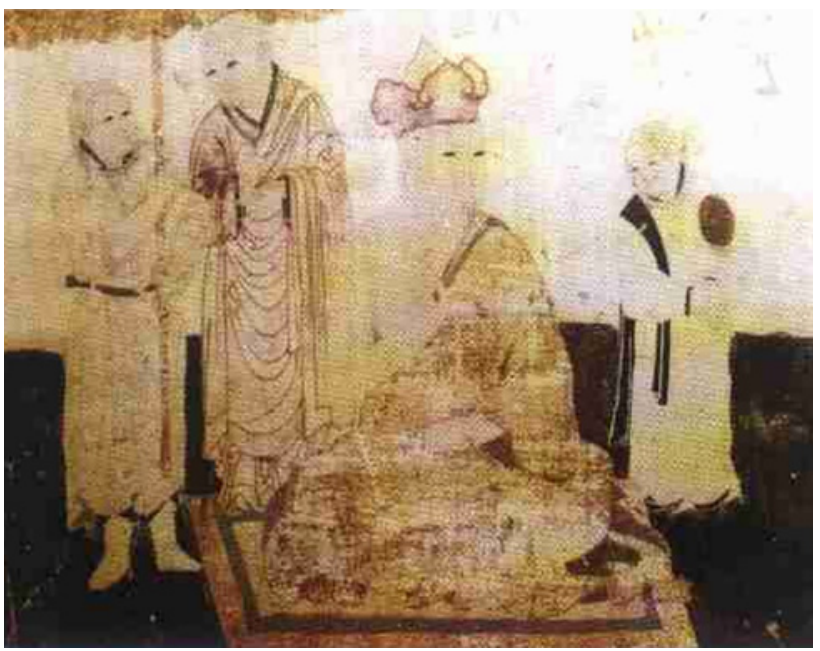

FIGURE 10.17

Buddhist master with white hat. Mogao Cave 464,

Dunhuang.

XIE JISHENG, "MOGAO KU DI 465 KU BIHUA HUA YU XIXIA KAO," 80 (PLATE 12)

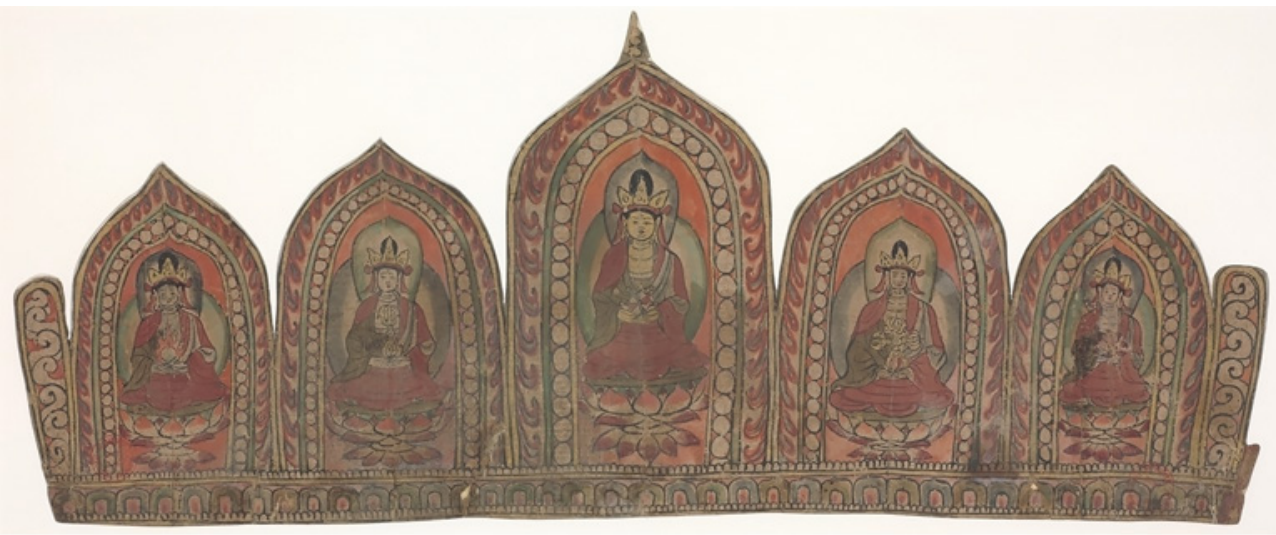

FIGURE 10.18 Buddha crown for Tantric ritual practice. Dunhuang. P. 4518 (7), (C) THE BRITISH LIBRARY BOARD

Tib. gTsang po pa dKon mchog seng ge), a disciple of the First Karmapa Düsum khenpa (1110-1193, Tib. Dus gsum mkhyen pa), who was sent to the Tangut Empire instead of the First Karmapa, when the latter refused the invitation of Emperor Renzong. We do not know exactly when Tsangpopa arrived in the Tangut capital, but given the general context and interest of Renzong in Tibetan Tantric Buddhism, some time in the late 118 os seems to be a realistic date. Tsangpopa eventually enjoyed the title of Imperial Preceptor in the Tangut Empire, ${ }^{41}$

41 Another important Tibetan who eventually received the title of Imperial Preceptor was the Barompa (Tib. 'Ba' rom pa) master Tishi Repa (1164/65-1236, Tib. Ti shri Sangs rgyas ras pa), who responded to Renzong's son and successor Huanzong's invitation to the 

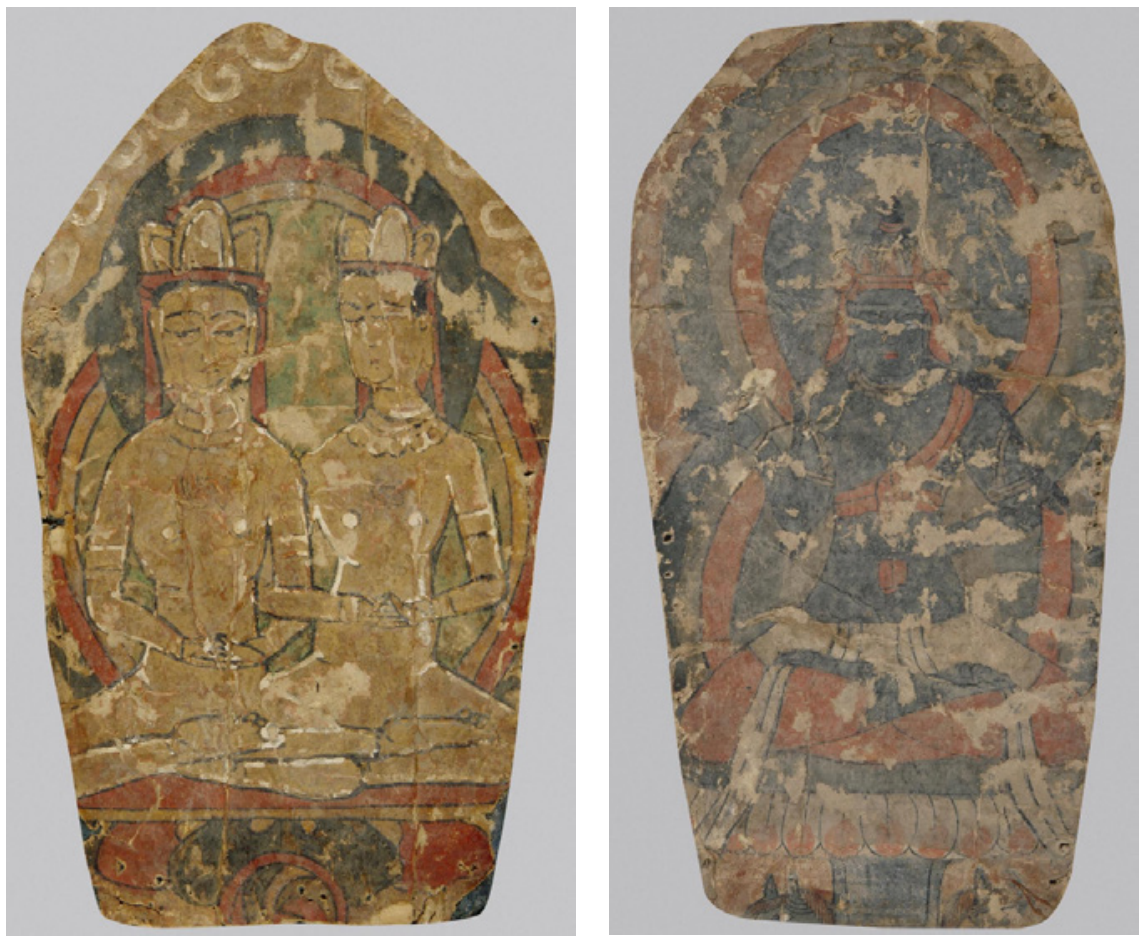

FIGURES 10.19-10.20 Fragments of crowns for Tantric ritual practice. Karakhoto.

X2500 (LEFT) AND X2503 (RIGHT), THE STATE HERMITAGE

MUSEUM, ST. PETERSBURG

an extraordinary position which, as I have indicated, was created in a time of need for Emperor Renzong (probably in the 1170s according to Ruth Dunnell). As a matter of fact, Tsangpopa was known to have received Vajravārāhī transmissions from the First Karmapa. In the important historical work of the Karmapas, the zLa ba chu shel gyi phreng ba [Garland of Finest Crystal Gems], first pointed out by Elliot Sperling, we find the following passage:

When the king of the Tangut [Empire] [...] invited the lord himself [, that is the First Karmapa Düsum khenpa], he sent Tsangpopa in his stead, having bestowed on him the development and completion stage teachings of Vajravārāhī and then exhorted him, [saying:] "Meditate in the Helan Mountains [near the Tangut capital]!" There he served as lama to

Tangut capital, ca. 1196/97 (r. 1194-1206). Cf. Elliot Sperling, "Further Remarks apropos of the 'Ba'-rom-pa and Tanguts," Orientalia Academiae Scientiarum Hungaricae 75.1 (2004): $9^{-10 .}$ 
the king of the Tangut [Empire] and received the appellation Tsangpa Tishi [, that is Imperial Preceptor Tsangpopa] ${ }^{42}$

I suggest that the Vajravārāhī teachings were among Tsangpopa's specialties, which he also taught in the Tangut Empire, so that his portrait might have found its way onto related Karakhoto thangkas. In fact, one more piece of visual evidence related to the Cakrasamuvara and Vajravārāhī cycles (and also related to depictions in the Mogao Caves and in one of the Karakhoto thangkas) was found close to the Tangut capital in a sealed chamber near the top of Hongfo stūpa (for the location of the site see map 10.1). There, a thangka was found depicting twelve-armed Cakrasamvara and Vajravāāhī, together with a Sinitic depiction of the planetary Buddha Tejaprabhā, both studied by Rob Linrothe. He suggests that both thangkas were sponsored by the same patron, and that any Buddhist monument built or restored close to the Tangut capital likely had imperial approval, given the record of Renzong's Buddhist patronage activities. ${ }^{43}$ A very similar depiction of a twelve-armed Cakrasamvara and Vajravārāhī was found in Karakhoto (x2369), ${ }^{44}$ in an arrangement that is, as the Chinese scholar Ruan Li discovered, identical to what once decorated the Western section of the Northern wall of Mogao Cave 465 in Dunhuang. ${ }^{45}$ Therefore, the popularity of the Vajravārāhī and Cakrasaṃvara cults was neither limited to the center nor to the periphery of the Tangut Empire, but was most probably initiated at the centre through the transmissions of Tibetan masters such as Tsangpopa.

42 The translation, with slight changes by myself, follows Elliot Sperling, "Lama to King of Hsia," The Journal of the Tibet Society 7 (1987): 33, Tibetan text on p. 48 (c). See also: Si tu pan chen Chos kyi 'byung gnas and 'Be lo Tshe dbang kun khyab, ed., sGrub brgyud Karma kam tshang brgyud pa rin po che'i rnam par thar pa rab 'byams nor bu zla ba chu shel gyi phreng ba (New Delhi, 1972), I f. 26v.

43 Linrothe, "Peripheral Visions: On Recent Finds of Tangut Buddhist Art," particularly p. 247. The images of both thangkas are found here on p. 237 (fig. 1) and 238 (fig. 2). See also Linrothe, "Xia Renzong and the Patronage of Tangut Buddhist Art," 95; Lei Runze, "The Structural Character and Tradition of Ningxia's Tangut Stupas," Orientations 27.4 (1996): 59 .

44 The Karakhoto thangka x2369 is published in: The State Hermitage Museum, Russia, Northwest University for Nationalities, and Shanghai Chinese Classics Publishing House, Khara-Khoto Art Relics Collected in the State Hermitage Museum of Russia, vol. 2, plate 130. Ruan Li, "Mogao ku di 465 ku mandaluo zaikao," 65. An image of the Western section of the Northern wall in Mogao Cave 465 is also published in: Yang Xiong and Wu Jian, Dunhuang shikuyishu. Mogao ku di siliuwu ku (Yuan), plate 107 (p. 135). 
Having sketched here the larger context of what I assert to be a deliberate creation of a network of Tantric sacred spaces within the Tangut realm, I put forth the following working hypothesis concerning Mogao Cave 465: If we accept that the Ușnịșavijayā maṇdala in Yulin Cave 3 (fig. 10.2) was produced on the occasion of Rengzong's sixtieth anniversary celebration in 1184, and depicts Renzong as the patron placed within the sacred narrative, then the choice was probably made by a devout Buddhist practitioner with the aspiration for a long and protected life and a favorable rebirth. In 1184, Renzong had another nine years to live. His reign marked the hight of the Tangut Empire, a very wealthy and cultured civilisation with an emperor regarded in the Buddhist world of his time as a Dharmarāja (Tib. chos kyi rgyal po), a Buddhist king, as we can see in correspondances of Tibetan Kagyü masters with Renzong. ${ }^{46}$ I suggest that for an emperor who has accomplished all worldly goals and who is a devout Buddhist practitioner, his spiritual aspirations would be given priority in his final years. As such, a spiritual teacher like the Tibetan master Tsangpopa, initiated in the Anuttarayogatantras, the Vajravārāhī cycle, by the First Karmapa, might have instructed Renzong the way to accomplish this goal. If we accept this scenario, we might also consider the possibility that Renzong could have acted as a patron of Mogao Cave 465, namely in the attempt to create a ritual space dedicated to Vajravāāāì and other Tantric deities under the guidance of

46 See for example the works of Jigten Gönpo (1143-1217, Tib. Jig rten mgon po) in which the Tangut kings are referred to as Buddhist kings: 'Bri gung Chos rje 'Jig rten mgon po Rin chen dpal, The Collected Works (Bka' 'bum) of Khams gsum chos kyi rgyal po Thub dBang Ratna Srī, ed. H.H. Drikung Kyabgon Chetsang (Konchog Tenzin Kunzang Thinley Lhundup) (Dehradun: Drikung Kagyu Institute, 2001), vol. 5, Se. 183, text no. 488. Jigten Gönpo, the founder of the Drigung Kagyü School (Tib. 'bri gung bka' brgyud pa), was in contact with the Tangut Emperors. He dispatched a symbolic gift of an image of Mañjughoșa to the Tangut court as a token of peace when the Mongols, under Činggiz Khan, first attacked the Tanguts in 1207. See Sperling, "Lama to King of Hsia," 32. Moreover, three fragments in Tibetan script from the Karakhoto Collection related to Jigten Gönpo evidence the relationship between the Drigung School and the Tangut court, namely IOL Tib M 959 (cat. no. 232), IOL Tib M 954 (cat. no. 270) and IOL Tib M 958 (cat. no. 274). The cat. nos. in brackets refer to the catalogue: Takeuchi and Iuchi, Tibetan Texts from Khara-Khoto in the Stein Collection of the British Library: Studies in Old Tibetan Texts from Central Asia. The three manuscripts are also briefly discussed in: Maho Iuchi, "Early Bka' brgyud Texts from Khara-Khoto in the Stein Collection of the British Library," Journal of Indian and Buddhist Studies 65.3 (2017): 233-238. Moreover, Cécile Ducher communicated to me in Paris in December 2017, that she found references in many biographies of Tibetan masters of the 12th century, indicating that they were eager to go to the land of the Tanguts. 
an accomplished master like Tsangpopa. After all, Cave 465 is a place remote from both the Tangut capital and the main centre of attention in the Mogao cave complex itself; it is situated at its very Northern end, surrounded by burial caves - a perfect place of Tantric ritual practice. In the end, this ritual space might even have served as the (secret) mortuary cave for Emperor Renzong. As a devout Buddhist practitioner, he potentially experienced the sacred dimension of the depicted enlightened beings, so that there was no need felt to depict an image of the donor-but this is mere speculation in the attempt to find an answer to the still open question concerning the lack of a donor figure in Cave 465. Thus, I suggest seeing the creation of Tantric sacred sites in Tangut lands as mirroring the very personal spiritual development (or even ascension) of the imperial donor Renzong, during the last few decades of the 12th century, a development that seems to have continued with his successors. 